\title{
Havana's changing urban agriculture landscape: A shift to the right?
}

Charles French, University of New Hampshire, Cooperative Extension/Department of Natural Resources and the Environment

Mimi Becker, University of New Hampshire, Department of Natural Resources and the Environment

Bruce Lindsay, University of New Hampshire, Department of Natural Resources and the Environment

Submitted 2 June 2010 / Accepted 3 December 2010/ Published online January 2011

Citation: French, C., Becker, M., \& Lindsay, B. (2010, Fall). Havana’s changing urban agriculture landscape: A shift to the right?. Journal of Agriculture, Food Systems, and Community Development, 1(2): 155-165. doi:10.5304/jafscd.2010.012.013

Copyright (C) 2011 New Leaf Associates, Inc.

\begin{abstract}
For two decades Havana, Cuba, has served as a living laboratory for practitioners and scholars of urban agriculture, particularly in its well-documented role in helping stave off food insecurity during a period of severe resource constraints. After the collapse of the Soviet Union in 1991 and the austere economic conditions that followed, the Cuban government enacted a series of radical agrarian reforms aimed at seeding the growth of private urban gardens - a new phenomenon in this country once dependent on trade subsidies and food rations. As a result of the reforms, close to 300 private urban agricultural cooperatives and

a Corresponding author: 204 Nesmith Hall, University of New Hampshire, Durham, NH 03820 USA; charlie.french@ unh.edu; +1-603-862-0316.

b 207b James Hall, University of New Hampshire, Durham, NH 03820 USA.

c 114 James Hall, University of New Hampshire, Durham, NH 03820 USA.
\end{abstract}

thousands of small home gardens sprouted up across Havana. Yet in the ensuing decade and a half, Cuba's increasing desire to integrate with the global economy, and its adoption of free-market principles, has forced the urban agriculture sector to make dramatic adjustments. Using secondary data, reports by other observers, and our own structured interviews with 11 of Havana's urban gardeners, this study examines the challenges and opportunities that urban agriculture has experienced, and will continue to experience, in Cuba's post-communist society. We hope to stimulate continuing inquiry into Havana's evolving urban agriculture scene, as it continues to provide valuable lessons for other cities in the Global North and South that are increasingly likely to experience their own future resource constraints and food insecurity.

\section{Keywords}

Havana, Cuba, urban agriculture, agricultural cooperatives, agricultural policy reform 


\section{Introduction}

As a socialist country abandoned during the collapsed Soviet Union and isolated by a lack of trade with many former trading partners, Cuba has provided a unique opportunity to study how nations and their urban communities in particular cope with resource limitation to maintain an adequate food supply. Over the last 60 years Cuba has had to restructure its agriculture sector to meet the needs of its citizens during various crises. Private industrial farms dominated the rural landscape prior to the revolution; communist-style, state-run megafarms took over after the revolution; and thousands of smaller farmer-owned cooperatives proliferated during the country's "Special Period" after the loss of Eastern Block support.

In aggressively addressing food insecurity, the Cuban government instituted reforms, such as giving citizens the right to use vacant land for the production and sale of food, encouraging farmers' markets (termed "kiosks"), as well as allowing the creation of privately owned cooperatives. Throughout Havana, urban agriculture burgeoned as residents realized this was a way for them to earn extra income (sometimes more than state salaries) as well as supplement their family food needs. Despite limited amounts of oil and petrochemicals to sustain food production, the country managed to stave off widespread hunger and malnutrition.

Recent indications suggest that agriculture and food system reforms have set the stage for yet another period of remarkable change, including some of Cuba's most liberal policies since the Revolution. Based on data we gathered and interviews we conducted with urban agriculturalists in Havana, we believe that Cuba is continuing its evolution toward an economy that includes more market-based reforms and individual freedomsa change that provides new opportunities and challenges in a post-communist society.

Using published data and interviews with a small sample of urban agriculture practitioners in Havana, we explore the recent past and current transformation taking place in the city's urban agriculture movement. In this paper we endeavor to encourage further inquiry into Cuba's rapidly changing urban food system that will lead to viable urban food production strategies for use in coping with a post-fossil fuel future.

\section{Revolution and Communist Control of Agriculture}

For the better part of the 20th century, sugarcane grown on large, corporate farms dominated Cuba's agricultural landscape, accounting for $90 \%$ of the country's exports by 1950 (Koont, 2004). In fact, $73.3 \%$ of the rural land was owned by less than $9.4 \%$ of the landholders, most of which were U.S.owned companies (Koont, 2004). One of the implications of this export-based agricultural system was that very little government policy was focused on achieving food security, as indicated by the widespread poverty, malnutrition, and class inequities that pervaded Cuba through the 1950s (Murphy, 1999).

When Fidel Castro and his revolutionary forces took control in 1959, however, corporate farms were seized and converted to state-run farms or were redistributed to landless farmers. The state also assumed control over the marketing and distribution of food through what was called the Acopio system of government procurement. Under Acopio, farmers kept a portion of the harvest, while the remainder was distributed by the government to Cuba's population through food rations (Murphy, 1999). Although state farms diversified their production to include staples for domestic consumption, sugarcane still dominated Cuba's agricultural landscape. It was the country's main trade commodity with the Soviet Union, for which Cuba received cheap petroleum, fertilizer, and food staples (Funes, Garcia, Bourque, Perez, \& Rosset, 2002).

\section{The Special Period}

When the Soviet Union collapsed in 1991, prices for Cuban sugar dropped while access to oil and capital goods at below-market prices was virtually cut off, launching Cuba into a period of economic and food insecurity known as the Periodo Especial en Tiempo de Paz, or the "Special Period in Times of Peace" (Murphy, 1999). At the onset of the 
Special Period, the average, daily per-capita caloric intake dropped from around 3,000 calories per day to less than 1,900 (Cruz \& Medina, 2003). As food scarcity heightened throughout Cuba in the early 1990s and food rations dropped sharply, the Cuban government feared that social unrest could lead to further economic instability, and ultimately, political instability. And with the emergence of a black market for foodstuffs, the government had little choice but to institute a series of agrarian reforms aimed at closing the food gap, particularly in Cuba's urban areas. Hard-liners were critical of reforms that drew from the principles of free market capitalism, but Castro rebutted, "This is no time for theorizing, but instead for advancing, resisting, and overcoming" (Eckstein, 1994, p. 96). Thus began a series of globally unprecedented economic and agricultural policy reforms aimed at national food self-sufficiency.

\section{Agrarian Reform and the Rise of Havana's Urban Agriculture Sector}

The first major Special Period reform was creation of the Urban Agriculture Program (UAP), which provided seeds, materials, land, and technical assistance to individuals and groups (Rosset $\&$ Medea, 1994). Although UAP provided these resources to urban gardeners, it handed decisionmaking power down to local Peoples' Councils to represent producers' interests (table 1).

Also significant was the restructuring of the land rights system to allow individuals and groups to obtain legal (usufruct) rights to use vacant, urban land for food production, with the caveat that the government can terminate the contract with due notice (Murphy, 1999). The Cuban Ministry of Agriculture (MINAG) followed suit by authorizing private and state-run agricultural markets, including small produce stands called "kiosks" as well as larger open-air markets where cooperative producers and individual farmers could sell farm products for profit (Bourque \& Canizares, 2000). By the mid-1990s, over $70 \%$ of food sold in Cuba came from sales at these new agricultural markets (Martín, 2002).
Table 1. Summary of UAP Reforms, 1991-1996

\section{State Support}

\section{Urban Agriculture Program (UAP)}

The Cuban Ministry of Agriculture instituted UAP in 1993 to set a precedent for urban agriculture. The program provided individuals and groups with seeds, materials, land, and technical support.

\section{Land Ownership}

\section{Usufruct Land Rights}

Resolution 289/90 gave individuals and groups usufruct rights to vacant land for agricultural production. By the mid-1990s, thousands of individuals and groups had gained land rights.

\section{Food Distribution System}

\section{Agricultural Markets}

Decree 191/94 authorized private producers and agricultural cooperatives to sell surplus produce, making urban agriculture the largest job-growth sector in Cuba by the mid-1990s.

\section{Organizational Structure}

Basic Units of Agricultural Production (UBPC) Bylaw 142/93 groups the right to organize, own what they produced, and sell surplus for a profit. This cooperative structure, known as the UBPC, was intended to replace state farms.

\section{Decision-Making Authority}

\section{People's Councils}

The government authorized the formation of these neighborhood grassroots bodies in 1994 to represent producers' interests and coordinate the provision of resources at the local level.

\section{Evolution of New Organizational Structures for Havana's Gardens}

The first of the private urban agricultural structures to emerge as a result of the Special Period reforms was the Basic Units of Cooperative Production (UBPC) (see figure 1). The government authorized the formation UBPCs in 1993 as a first step to phasing out the state-run cooperative farms, particularly those located in and around urban areas, and replacing them with cooperatives 
managed by citizens (Alvarez, 2000). Unlike state farms, UBPCs can elect their leaders, gain temporary legal rights to land, and sell what they produce, albeit a portion of the produce must be sold to the state at below-market prices (Nova Gonzáles, 2006). Havana's UBPCs are quite small compared to others in more rural districts, employing from 5 to 80 members, and ranging in size from one to several hectares (see one location in figure 2). Note that the majority of Havana's UBPCs are organoponicos, gardens located on infertile soils with poor moisture retention that require irrigation and the addition of organic matter in raised beds (Funes, et al., 2002).

However, with prices soaring in the early days, members could earn up to six times typical state wages. By the mid-1990s, there were about 300 UBPCs. Some were converted from state farms, while others were situated on vacant lands, old dumps, and demolished building sites. UBPCs in Havana are generally cultivated with staples such as lettuce, tomato, beans, squash, and herbs, as well as fruits such as plantain, banana, and mango (E. Fuster, director of the Cuban Association of Agroforestry Techniques, personal interview, 14 January 2007).

Paralleling the emergence of UBPCs, two forms of smallholding, private gardens also flourished: parcelas and patios. Parcelas are small gardens ( $<1,000$ sq. meters or $<10,764$ sq. feet) planted on vacant lots granted to individuals and

\section{Figure 1. Members of a UBPC-managed organoponico in Havana lay composted material on raised beds.}

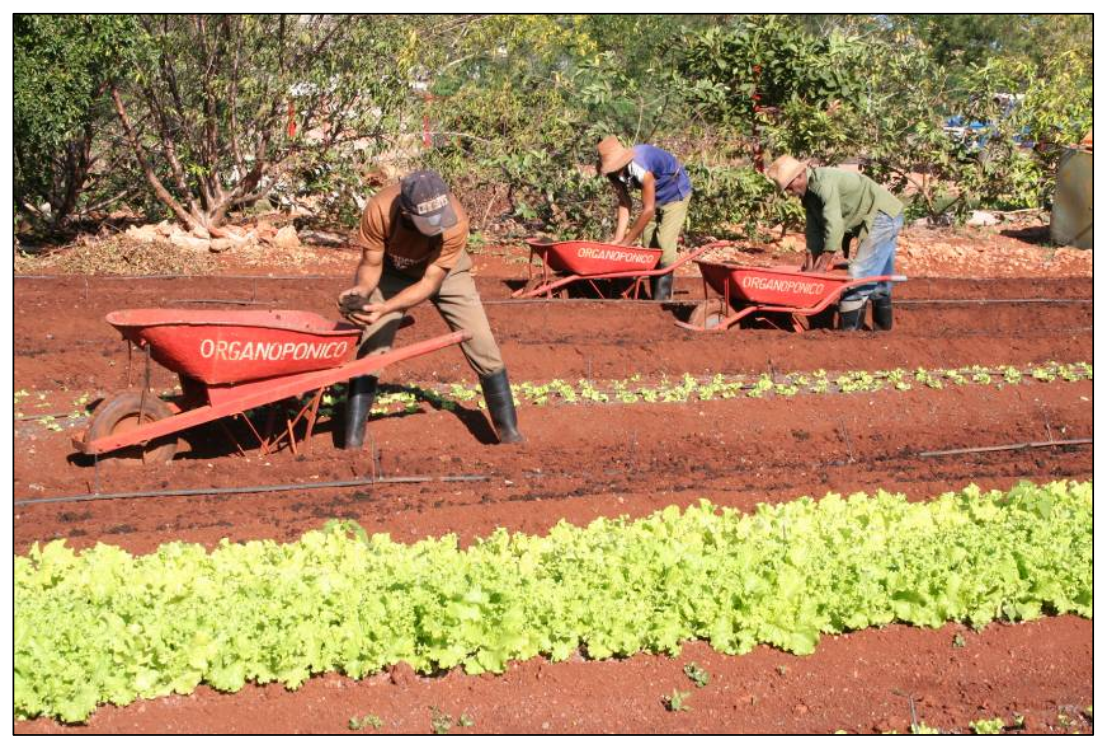

\section{Figure 2. Google Map of Havana Este where one of the UBPCs (Vivero Organopónico Alamar) is located.}

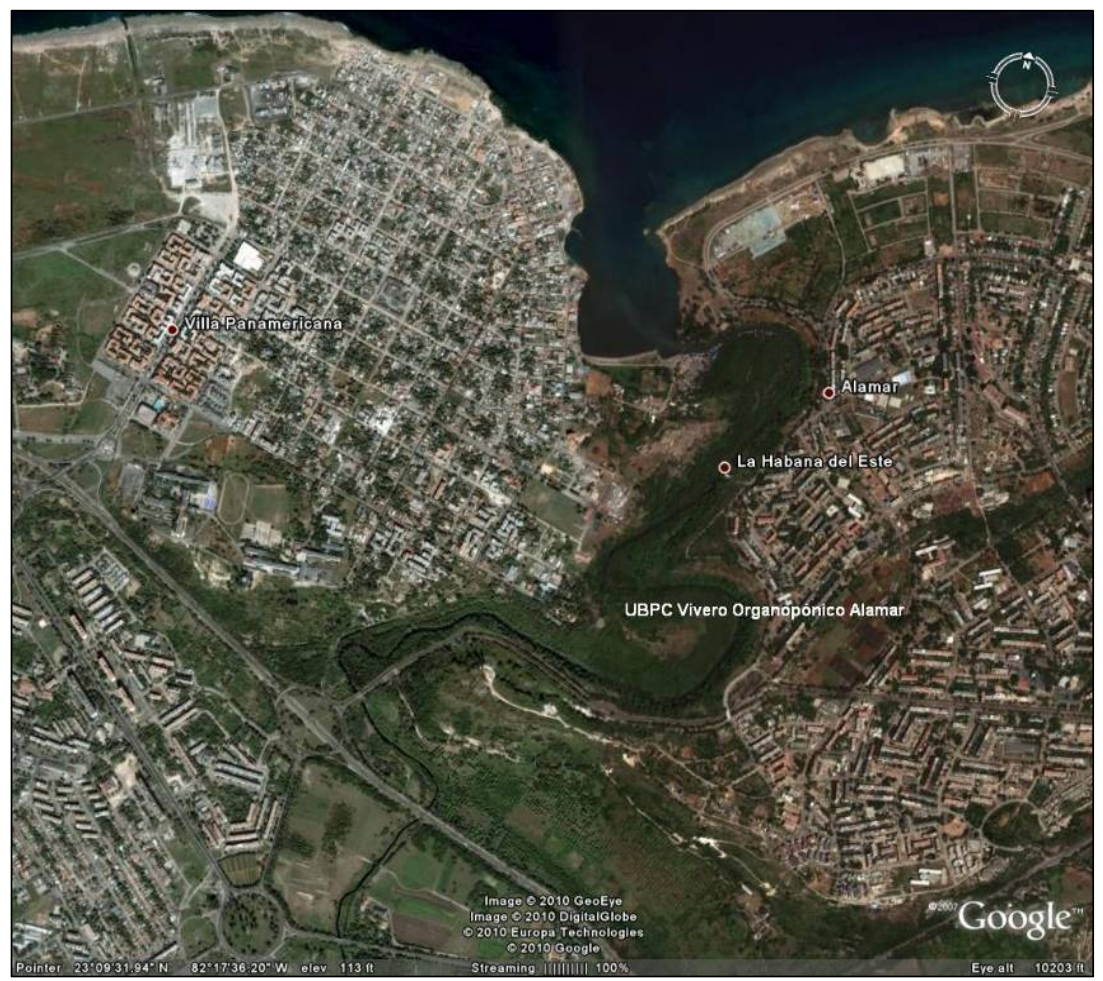

groups by the state, typically close to peoples' homes (see figure 3). Patios are patio gardens that consist of fruits and vegetables planted in peoples' 
Figure 3. Parcela gardeners in Havana's La Coronela neighborhood.

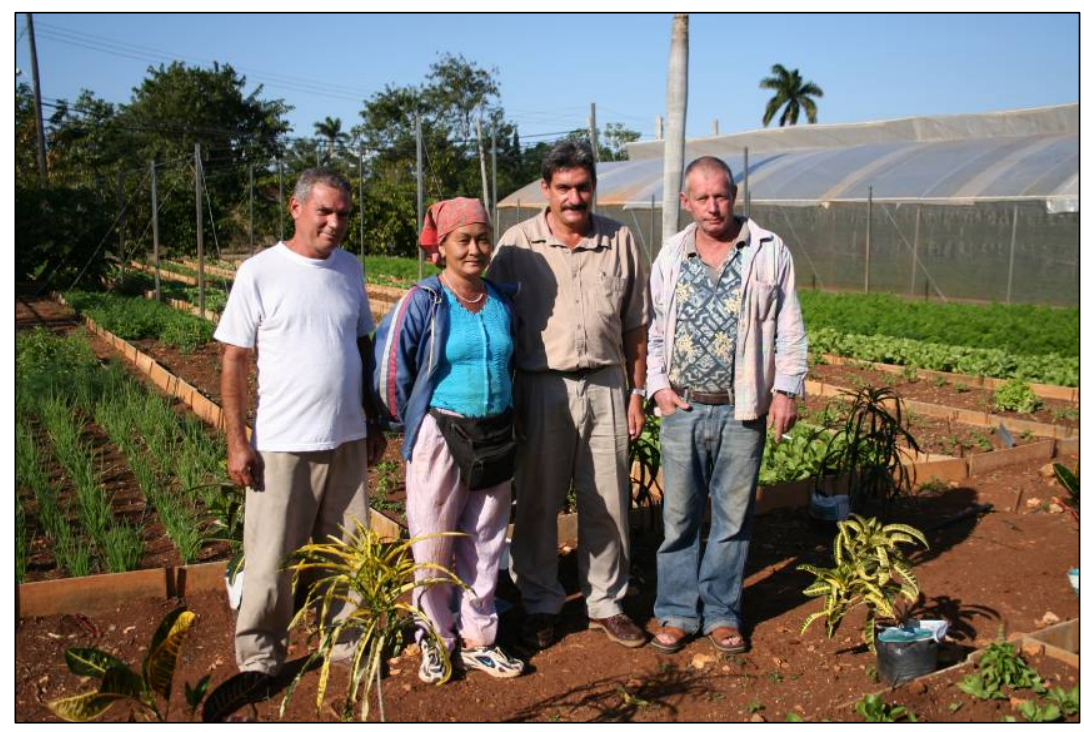

\section{Figure 4. Gardener in her patio garden in Havana's Versalles neighborhood.}

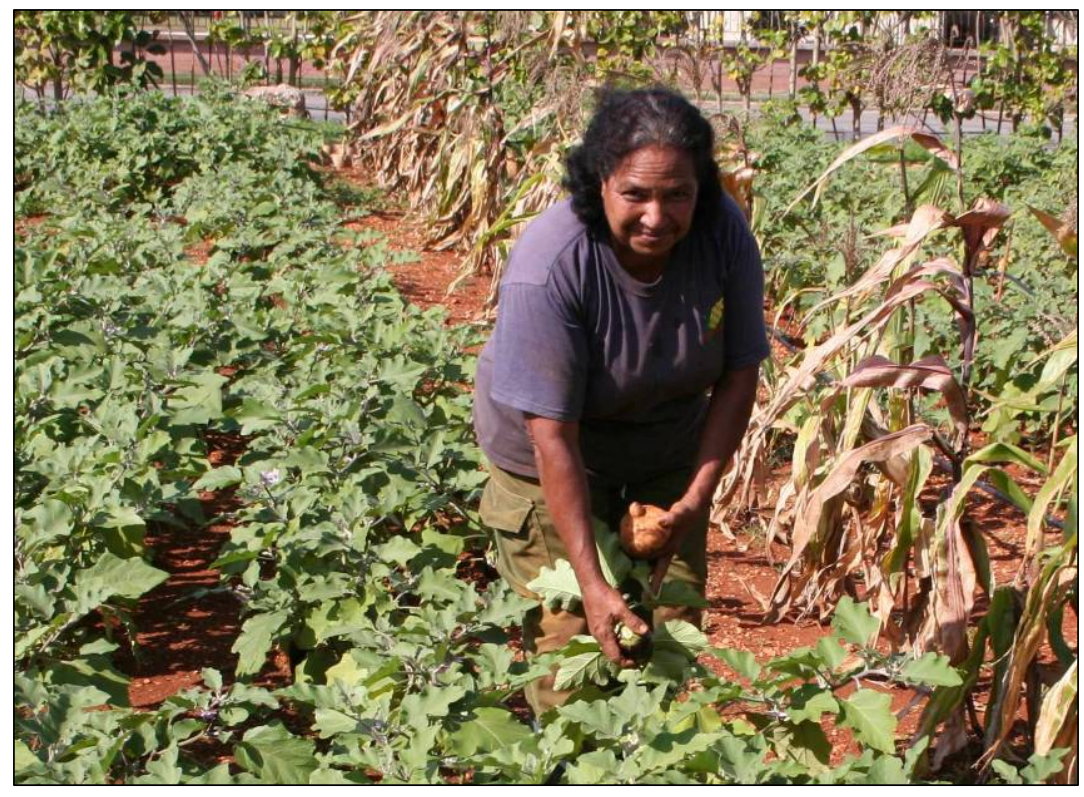

(12,355 acres) to 10,000 hectares (24,711 acres) (MINAG, 1996). It has been reported that by the late 1990s, urban agriculture represented the country's largest job-growth sector, exceeding rural agriculture (Koont, 2004).

\section{Cuba's Economic Recovery}

At the close of the millennium, however, Cuba's economy was recovering through a combination of successful austerity policies and new trading partners. Yet the evolution of the Cuban food system continued and a curious trend began. While the number of home gardens in Havana continued to grow, the small grower cooperatives (UBPCs) that had been so effective in using larger vacant parcels in the city of Havana for food production suddenly declined dramatically, and today there is some question as to whether they will survive at all.

\section{As Cuba emerged from the} difficult early stages of the Special Period in the mid- to late 1990s, there was a shift in these trends as UBPCs began to decline sharply in relation to the growth of parcelas and family-owned patios. Cruz and Medina suggest that the decline of UBPCs in Havana is a result of growth in other sectors of the economy as the country began to

dooryards (see figure 4). During the early years of this reformation, the number of private, home gardens in Havana grew from relatively few to over 26,000 by 1996 (Cruz \& Medina, 2003).

As a result of the emergence of parcelas, patio gardens, and UBPCs, the area in agricultural production doubled in Havana between 1991 and 1996, increasing from approximately 5,000 hectares recover from the economic crisis that dominated the early 1990s (Cruz \& Medina, 2003). Not only did a surge in tourism and manufacturing starting in the late 1990s create new demands for open lots-allegedly resulting in the government's termination of several UBPCs' legal rights to the land upon which they were situated-but these sectors also drew workers away from food cultivation as the Cuban economy recovered. 
Table 2: Change in the Number of Urban Gardens by Type in Havana, 1996-2005

\begin{tabular}{l|c|c|c|c}
\hline & 1996 Total & 2005 Total & Net change & $\%$ change \\
\hline UBPCs & 292 & 44 & -248 & $-85 \%$ \\
\hline Patios and Parcelas & 26,000 & 49,508 & 23,508 & $90 \%$ \\
\hline
\end{tabular}

Sources: MINAG, 1996; MINAG, 2005.

Other factors reportedly contributing to the decline of UBPCs include lack of state support, price caps on agricultural sales, lack of autonomy by producer groups, and debts inherited by cooperatives for the purchase of equipment (Buchmann, 2009; Nova González, 2006; Mesa-Lago, 2008).

MINAG statistics indicate that of the 292 UBPCs established in Havana by 1996, only 44 remained in 2005, an 85\% decline (MINAG, 2005) (see table 2). A recent article by a Cuban journalist indicates that, nationally, the number of UBPCs declined by $10 \%$ between 2008 and 2009 (Perez, 2009).

Meanwhile, the number of parcelas and patios rose sharply in Havana during this period. In 2000, the government instituted "The Official Movement of Patios and Parcelas" to further increase production in small spaces around people's homes in order to preserve larger, high-value urban spaces (Premat, 2003). In total, the number of parcelas and patios nearly doubled between 1996 and 2005 (see table 2). ${ }^{1}$ These gardens have helped backstop the loss of UBPCs, as former UBPC members began to cultivate their own gardens near their homes (Buchmann, 2009).

\section{Continuing Reformation in Havana's Urban Agriculture}

More recently, in August 2009 the government announced the creation of the Programa de Agricultura Suburbana (Suburban Agriculture Program), aimed at promoting larger-scale farms in the suburban periphery-10 kilometers (6.2 miles) outside of provincial capitals and five kilometers

\footnotetext{
${ }^{1}$ Prior to 2000, patios and parcelas were grouped under one category: "popular gardens."
}

(3.1 miles) outside of municipal capitalswhere it is estimated that 600,000 hectares $(1.48$ million acres) of unused space is available (Grogg, 2010). The suburban agriculture program appears to represent the government's new policy to shift significant food production away from urban centers and back to the urban fringe, where much of the country's agricultural production was focused just a few decades ago.

Havana's urban gardeners perceive this policy to have major implications. However, without access to information about recent government policy changes or statistical projections to peer into Havana's food future, the authors felt that a scoping trip to Havana-whereby we could interview urban gardeners, access Ministry of Agriculture data, and interface with Cuban officials — would help to fill the knowledge gaps and enable us to view first-hand the rapidly changing urban agriculture sector. Given the significant hurdles in securing permission from the State Department to conduct research in Cuba, only the primary author, also being fluent in Spanish, was able to go.

With regard to the selection of subjects for the scoping study, purposive, quota sampling was used, whereby respondents were selected to represent each of three major organizational structures experiencing rapid change that emerged from secondary data analysis: UBPCs, patios and parcelas. The sample of each organizational structure was not intended to be proportional to their respective membership, since the purpose of the sampling was not to make statistical inferences, but rather to gain a better understanding of the factors contributing to the changing urban agricultural landscape in Havana. Thus, individuals representing each sector were selected based on their knowledge and years of experience in urban agriculture. 
Interview subjects were selected from nine of Havana's 15 municipal districts based on a list of urban community gardens maintained by the Asociación Cubana de Téchnicos Agrícolas y Forestales (ACTAF). Four were members of UBPCs, three tended parcelas and four tended patios (see figure 5). An ACTAF representative was present for four interviews, but with the stipulation from the authors' institution's Institutional Review Board that the subjects first give permission and remain anonymous.

The interview guide included 30 open- and closeended questions. Interviews were recorded for all but two subjects who asked not to be taped. The questions focused on why they participated in their particular garden, what benefits and challenges they perceived considering their garden's organizational structure, as well as their outlook for the future of urban agriculture. Interview transcripts, along with direct observations for each garden, were imported into NVIVO 8.1, a qualitative analysis software program. Open coding was used to identify common response themes, or data categories, and sort the transcript data into these themes. We concede that the number of interviewees is small;

Figure 5. Map of community garden interview sites in Havana.

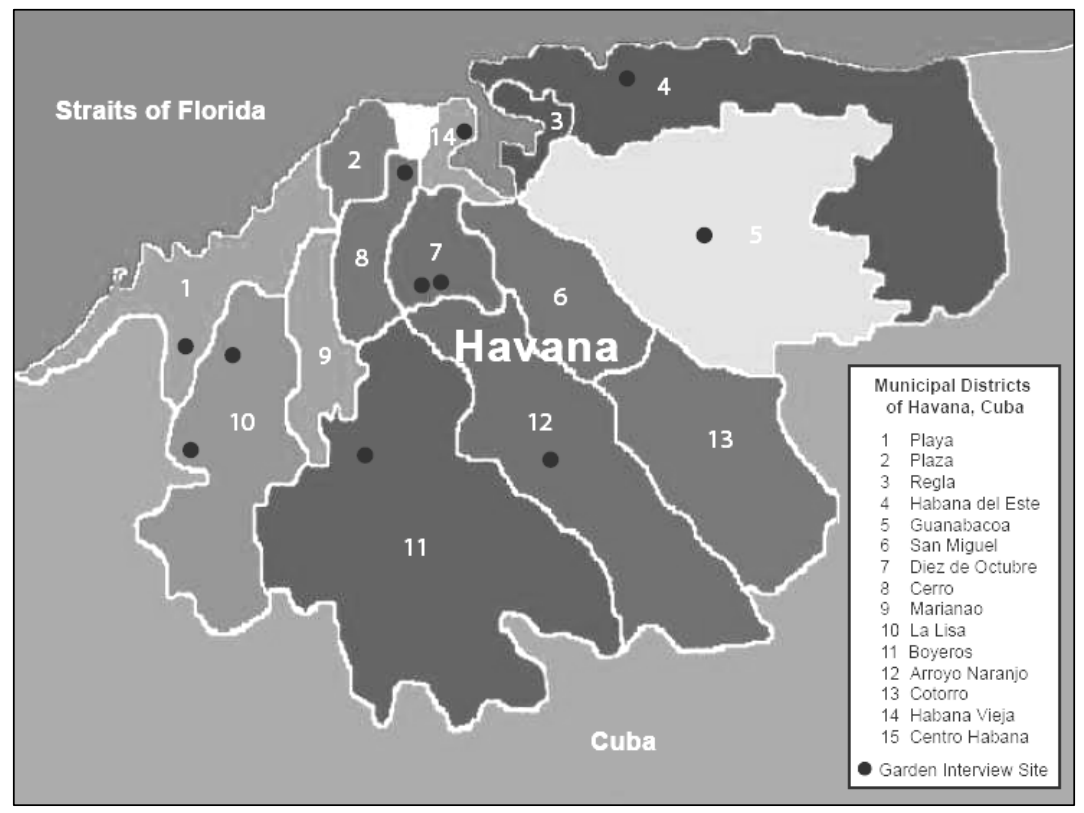

Map base courtesy of the Asociación Cubana de Téchnicos Agrícolas y Forestales (ACTAF). however, we believe that collectively their views are illustrative of the impacts government policy is having on urban gardeners and that the results provide a basis for future research on the cutting edge of Havana's urban agriculture. The following summarizes the major findings from the interview data (see table 3 for a summary of findings).

\section{Havana Urban Gardeners' Perceptions of Change in Urban Agriculture}

\section{Motivation to Garden}

UBPC members cited income as the key reason for gardening. Due to the scale of UBPCs and efficiencies gained by sharing responsibility for production, harvesting, management, and sales, they saw more opportunity to earn income through their UBPCs than if they cultivated independently. As one UBPC member noted, "Our goal is to earn money-that is why we formed the UBPC!"

The parcela gardeners reported that they gardened principally to put food on the table, but also to supplement their income. One noted that the food they produced went a long way to reduce household food expenses, while the other two said they routinely sold a portion of their harvest through a credit and service cooperative (CCS), a structure that provides independent farmers with access to credit, machinery, seeds, technical assistance, and markets.

Most patio gardeners indicated that they grew food for home consumption. One, who happened to have a significantly larger plot than the others, earned income through direct sales. She indicated that her patio gave her more independence than a UBPC would. The other three patio gardeners all had jobs with the state and suggested that gardening close to home was the best option for them to provide food for the table. As one noted, "I have a full- 
time job, but my family and I grow vegetables to eat because the cost of food is so high."

\section{Individual Challenges}

UBPC members complained that management of the cooperative was the biggest issue. In the words of one UBPC farmer, "We see a lot of turnover of members and it is getting harder to manage the cooperative and split the proceeds. We just don't have the experience to manage the UBPC." He indicated that a number of UBPCs in Havana had disbanded due to lack of leadership. Another UBPC member indicated that some of Cuba's changing policies and supports made it difficult for his UBPC, such as changes in the proportion of the harvest required to be sold through the Acopio system, reduced access to financing, and the changing requirements on what the UBPC is authorized to grow by the state. As well, new price caps imposed by the state on food sold by the UBPC cut into their proceeds. Furthermore, his UBPC was now required to pay the state a fee for use of the land. In the words of this individual, "the challenges of managing a UBPC — sharing the proceeds, lack of leadership, and fears that the state will take the land-make UBPCs a dying breed in Havana."

Patio and parcela gardeners indicated that their biggest challenge was access to resources and materials. Materials and resources most frequently cited were tools, quality seeds, tilling equipment, water access, and help with pest management. One also noted that there are not enough agricultural extensionists to meet their technical assistance needs. He said, "Some of us have little experience with growing food and we need help...We need resources to get us started." Another noted, "Unless the government helps me with pest control, it's not worth harvesting my garden."

Two parcela gardeners who sold produce through a CCS noted that state taxes on their produce sales were increasingly cutting into their profits. In contrast, the patio gardeners were generally not concerned about new regulations or taxes, since three of the four did not sell their produce.

\section{Future Outlook}

When asked what they perceived the future of their own garden to hold, the responses were striking. UBPC members were mainly concerned with retaining land tenure. One UBPC member described how several UBPCs had folded since 2000 because the land was appropriated by the state for other uses. Their contract explicitly stated that they had indefinite usufruct rights to the land, meaning that there was no long-term guarantee. UBPC members also shared concerns that regulations on the sale of food through the system of open agricultural markets would increase, and that new taxes would be imposed, thus reducing their profits. Not only had price caps been instituted after the Special Period, but a portion of UBPCs' produce now has to be sold through the Acopio system. Confirming the bleak outlook on the future of many UBPCs, one indicated that he doubted that they would still be in business in five years.

In contrast, the patio and parcela gardeners were not concerned that the state would take their land, since they gardened on undevelopable parcels around their homes. One patio gardener indicated that he had once been a UBPC member, but was forced to get a job at a hotel due to a sense of uncertainty of the future of his UBPC. He said, "I decided to grow food at home instead because there is more opportunity for growth."

All but one of the parcela and patio gardeners said that they saw an opportunity to increase their productivity, and sales of vegetables and ornamentals. At the same time, they said that the government would need to provide additional support to them.

\section{Outlook on the Future of the Urban Agriculture Sector}

Interviewees' views on the perceived future of the urban agriculture sector varied widely. There was, however, broad sentiment by UBPC members, parcela gardeners, and patio gardeners alike that the government was changing how it supported urban agriculture. One patio gardener noted, "The government helped us get started in the early '90s. But 
Table 3: Summary of Interview Findings

\begin{tabular}{|c|c|c|c|c|}
\hline & Motivation & Challenges & $\begin{array}{l}\text { Outlook for } \\
\text { Their Garden }\end{array}$ & $\begin{array}{c}\text { Outlook for } \\
\text { Urban Agriculture }\end{array}$ \\
\hline UBPCs & - Income & $\begin{array}{l}\text { - } \text { Changing } \\
\text { regulations } \\
\text { - Management and } \\
\text { leadership }\end{array}$ & $\begin{array}{l}\text { Fear that } \\
\text { government will take } \\
\text { land away } \\
\text { - Fear of new taxes } \\
\text { being imposed }\end{array}$ & $\begin{array}{l}\text { Foresee an urban ag } \\
\text { landscape without } \\
\text { UBPCs }\end{array}$ \\
\hline Parcelas & $\begin{array}{l}\text { - Food for the } \\
\text { household } \\
\text { - Independence }\end{array}$ & $\begin{array}{l}\text { - Access to materials/ } \\
\text { resources } \\
\text { - Taxes imposed on } \\
\text { the sale of produce }\end{array}$ & $\begin{array}{l}\text { - Opportunity to } \\
\text { increase sales } \\
\text { - Lack of government } \\
\text { support }\end{array}$ & $\begin{array}{l}\text { Predict that urban } \\
\text { ag sector will adapt } \\
\text { to changing times }\end{array}$ \\
\hline Patios & $\begin{array}{l}\text { - Food for the } \\
\text { household } \\
\text { - Income } \\
\text { - Independence }\end{array}$ & $\begin{array}{l}\text { Difficulty accessing } \\
\text { resources and } \\
\text { technical assistance }\end{array}$ & $\begin{array}{l}\text { - Opportunity to } \\
\text { increase production } \\
\text { - Lack of government } \\
\text { support }\end{array}$ & $\begin{array}{l}\text { Foresee reduced } \\
\text { support for urban ag } \\
\text { sector as a whole }\end{array}$ \\
\hline
\end{tabular}

now that the crisis has passed, we won't likely see that same level of support."

One UBPC member suggested that he didn't think there would be many UBPCs left in the city in a few years. Land values are rising due to growing tourism and other industries, and any support that the government would provide for urban agriculture would likely go toward helping people cultivate parcels that were not suitable for other purposes, like hotels.

Finally, a parcela gardener noted that things were changing rapidly in Havana and that the sector would have to change with the times as well to stay viable. The fact that the government's regulations and supports are shifting to cultivation of small parcels doesn't mean that Cuba has given up on urban farmers as a whole, he suggested. "It means that the tough conditions that lead to the Special Period reforms are over. New reforms may not be as supportive of the smaller farmer."

\section{Discussion and Conclusions}

The rise of urban agriculture in Havana is a compelling story that continues to inspire gardeners, NGO and agency staffers, and scholars around the world. Indeed, the city provides a testament to the resiliency of human beings under duress, and this is appealing on many levels. However, our exploratory study finds that Havana's urban agricultural landscape continues to evolve in ways that may surprise some observers and disappoint others. Cuba is continually adjusting in response not only to its limitations and local political winds, but also to the sirens of the global economy. Indeed, our Havana interviewees suggest that the Cuban government is changing its urban agriculture policy to reflect the perceived "greater" economic interests of the nation.

As the cultivation of small parcels close to peoples' homes supplements household food and income and poses no direct threat to the growth of Havana's core urban areas, it will be encouraged (or at least, not discouraged). However, the growth of agricultural production on the urban periphery now being emphasized will likely affect the remaining larger garden parcels in Havana proper, which have been the domain of the privately held cooperatives. While the lack of effective leadership and good management appears to have caused many of Havana's once vaunted urban farm cooperatives to fold over the past 10 years, government neglect, price caps placed on the direct sales of produce (forcing producers to sell a portion of their harvest to the state at below-market prices), and the appropriation of their valuable real estate for develop- 
ment in total clearly signal a new phase in the evolution of Havana's urban agriculture.

As the state takes away with one hand and gives with another, interesting questions arise: Will Havana's remaining UBPCs and their urban spaces painstakingly cultivated into organic oases now give rise to world-class hotels and office complexes? And what of the long-term viability of the privately owned periphery farms? Fidel Castro's recent statement to Jeffrey Goldberg from The Atlantic that, "The Cuban model doesn't even work for us anymore," is a pretty clear indication of Cuba's future direction (Campo-Flores \& Bast, 2010). As Cuba continues to experiment with private ownership, efficiencies, and free markets, how will it deal with capitalism's comorbidities, including competition, consolidation, industrialization, and monopolization? The most exciting development to watch may be how Cuba fosters freedom while also trying to find the elusive balance of interests that urban and periurban agriculture need in order to be sustainable in the long run. Only time will tell. But one thing is for sure: Havana may become even more valuable as a living laboratory for the rest of us as it becomes increasingly like other cities in the Global North in the years to come, and the new suburban agriculture program now being instituted in the hinterlands of Havana informs our own attempts at peripheral or "metropolitan" agriculture. We have much to learn from the urban agricultural experiment that is Havana's rapidly evolving food system.

\section{Acknowledgements}

Special thanks go to Eugenio Fuster and Castillano with of the Cuban Association of Agroforestry Techniques (ACTAF) for providing orientation to Havana's diverse urban gardens.

\section{References}

Alvarez, J. (2000). Differences in agricultural productivity in Cuba's state and nonstate sectors: further evidence. Cuba in Transition. Reston, VA: American Society of Civil Engineers.

Bourque, M., \& Canizares, K. (2000). Agricultura urbana en produccion de alimentos en la comunidad, por la comunidad y para la comunidad. Oakland, CA: Policy Institute on Food and Development.

Buchmann, C. (2009). Cuban home gardens and their role in social-ecological resilience. Human Ecology, 37(6), 705-721. doi:10.1007/s10745-009-9283-9

Butterfield, B. (2009). The impact of home and community gardening in America: National garden survey. Proceedings from the 5th Annual Garden Writers Web Teleconference, February 25, 2009.

Campo-Flores, A., \& Bast, A. (2010, September 13). Fidel tells the truth in Cuba. Newsweek, Vol. 155.

Chaplowe, S. (1996). Havana's popular gardens: Sustainable urban agriculture. City Farmer, 5(22), 1-7.

Cruz, M., \& Medina. R. (2003). Agriculture in the city: A key to sustainability in Havana, Cuba. Kingston, Jamaica: Ian Randall Publishers.

Eckstein, S. (1994). Back from the future: Cuba under Castro. London: Routledge.

Funes, F., Garcia, L., Bourque, M., Perez, N., \& Rosset, P. (Eds.). (2002). Sustainable agriculture and resistance: Transforming food production in Cuba. Oakland, CA: Food First Books.

Gleissman, S., \& Resemey, M. (Eds). (2010). The conversion to sustainable agriculture: Principles, processes and practices. Boca Raton, FL: CRC Press.

Grogg, P. (2007). Agriculture-Cuba: Waiting for announced reforms. Published by Inter-Press Service. Retrieved from http://ipsnews.net/ news.asp?idnews $=40349$

Grogg, P. (2010). Sustainable agriculture moves to the suburbs. Published by Inter-Press Service. Retrieved from http://ipsnews.net/news. asp?idnews $=51296$

Koont, S. (2004). Food security in Cuba. Monthly Review, 55(8), 11-20.

Martín, L. (2002). Transforming the Cuban countryside: Property, markets and technological change. Chapter 4 in F. Funes, L. Garcia., L. Borque., N. Perez., and P. Rosset. (Eds.), Sustainable agriculture and resistance: Transforming food production in Cuba. Oakland, CA: Food First Books.

Mesa-Lago, C. (2008). The Cuban economy in 20062007. Cuba in Transition, 17.

MINAG. (1996). Informes Anuales de la Empresa Horticula Metropolitana.

MINAG. (2005). Informes Anuales de la Empresa Horticula Metropolitana.

Murphy, C. (1999). Cultivating Havana: Urban agriculture and food security in the years of crisis. Development Report No. 12. Oakland, CA: Food First Books. 
Nova González, A. (2006). La agricultura en Cuba: Evolución y trayectoria (1959-2005). La Habana: Editorial Ciencias Sociales.

Perez, J. (2009). “Aciertos y desaciertos de las UBPC segun el granma. Cuba Independiente. Accessed from http://cubaindependiente.blogspot.com/ 2009/12/aciertos-y-desaciertos-de-las-ubpc.html
Premat, A. (2003). Small-scale urban agriculture in Havana and the reproduction of the "New Man" in contemporary Cuba. Revista Europa de Estudios Latinoamericanos y del Caribe, 75, 85-99.

Rosset, P., \& B. Medea. (1994). The greening of the revolution: Cuba's experiment with organic agriculture. Sydney, Australia: Ocean Press. 
Journal of Agriculture, Food Systems, and Community Development ISSN: 2152-0801 online

www.AgDevJournal.com 